Directions in Sexual Harassment Law 



$$
\begin{array}{r}
\text { EDITED B Y } \\
\text { CATHARINE A. MA C K IN O N } \\
\text { AND REVA B. SIEGEL }
\end{array}
$$

\section{Directions in Sexual Harassment Law}

Yale University Press

New Haven \&

London 
Published with assistance from the Louis Stern Memorial Fund.

Copyright (C) 2004 by Yale University. Chapter I 3 copyright (C) 2004 by Janet

Halley. Chapter I 4 copyright (C) 2004 by Marc Spindelman. Chapter I 6 copyright (C) 2004 by Judith Resnik. Chapter 30 copyright (C) 2004 by Sally F. Goldfarb. Afterword copyright $\odot 2004$ by Catharine A. MacKinnon.

All rights reserved. This book may not be reproduced, in whole or in part, including illustrations, in any form (beyond that copying permitted by Sections I07 and I08 of the U.S. Copyright Law and except by reviewers for the public press), without written permission from the publishers.

Set in Sabon type by Keystone Typesetting, Inc.

Printed in the United States of America.

Library of Congress Cataloging-in-Publication Data

Directions in sexual harassment law / edited by Catharine A. MacKinnon and Reva B. Siegel.

p. cm.

Includes index.

ISBN 0-300-09800-6 (alk. paper)

I. Sexual harassment - Law and legislation - United States. 2. Sexual harassment - Law and legislation. I. MacKinnon, Catharine A. II. Siegel, Reva B.

$\mathrm{KF}_{475} 8 . \mathrm{D}+$ 2003050086

A catalogue record for this book is available from the British Library.

The paper in this book meets the guidelines for permanence and durability of the Committee on Production Guidelines for Book Longevity of the Council on Library Resources.

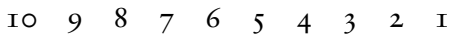

